\title{
SOCIAL INFRASTRUCTURE SERVICES FOR PROMOTING LOCAL COMMUNITY WELLBEING IN LITHUANIA
}

\author{
Gintarè Vaznonienè, Ilona Kiaušienè ${ }^{1}$
}

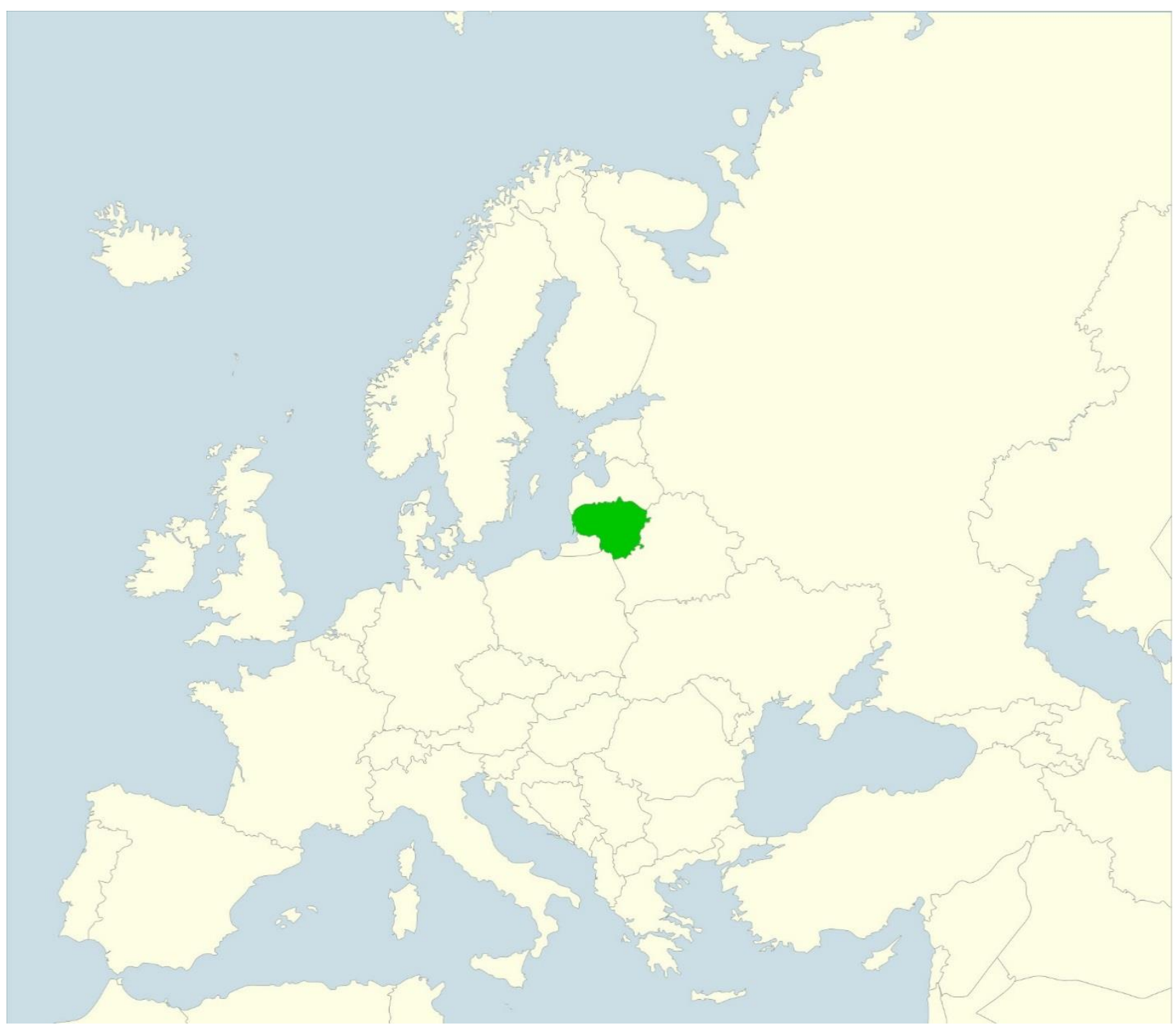

${ }^{1}$ Assoc. prof. dr. Gintarè Vaznonienè, Assoc. prof. dr. Ilona Kiaušienè, Business and Rural Development Management Institute, Faculty of Economics and Management, Aleksandras Stulginskis University, Universitetas st. 10 - 408 , LT53361 Akademija, Kaunas distr., Lithuania, e-mails: gintarej@gmail.com, ilona.kiausiene@asu.It 
Abstract: Social infrastructure is largely related to various services for community, facilities and public spaces, relationships and networks among local community members. It is therefore obvious that social infrastructure could be viewed as an important factor for creating better opportunities for integration and participation in society, fostering functional capabilities of a community, acknowledging human rights, improving judgements related to overall life satisfaction. The links between social infrastructure services and focus on local community wellbeing in Lithuanian's social science discourse has not been substantiated sufficiently yet. Consequently, this article aims at disclosing the importance of social infrastructure services in promotion of local community wellbeing. The research question of this article is formulated as follows: how social infrastructure services contribute and could promote wellbeing of local community. The methodological background is based on both theoretical and empirical findings pertaining to the topic. The research results have suggested that the need of local community for social infrastructure services should be evaluated more carefully in the context of wellbeing. These services have been found to play significant role in reaching a certain level of wellbeing in view of the place where people live, how they feel and how to evaluate the future of their living.

Key words: social infrastructure, social infrastructure services, local community, rural areas, wellbeing

Santrauka: Socialinė infrastruktūra dažnai apibrėžiama, kaip įvairios paslaugos teikiamos vietos gyventojams (bendruomenei), patogumai ir viešos erdvès, ryšius ir bendravimo tinklus tarp vietos gyventojų formuojantis vietovès elementas. Taip pat pažymètina, kad socialinè infrastruktūra gali būti vertinama ir kaip svarbus veiksnys sukuriantis sąlygas sékmingesnei integracijai ir dalyvavimui visuomeniniame gyvenime, atveria didesnes galimybes vietos gyventojams, užtikrina žmogiškujų teisių realizavimą, prisideda prie aukštesnès gyvenimo gerovės kūrimo. Socialinès infrastruktūros paslaugu svarbos vietos bendruomenès gyvenimo gerovei klausimas Lietuvos socialinių mokslų diskurse išplètotas nepakankamai. Šiame straipsnyje keliamas tyrimo tikslas išanalizuoti, kaip socialinès infrastruktūros paslaugos prisideda ir skatina vietos benduomenès gerovę. Tyrimas buvo atliktas pritaikius teorinius ir empirinius tyrimo metodus. Tyrimo rezultatai parodè, kad poreikių socialinès infrastruktūros paslaugoms nustatymas gyventojų gerovès kontekste yra per mažai nagrinėjamas, nors ir yra neabejotina sąlyga siekiant aukštesnès jų gyvenimo gerovès. Socialinès infrastruktūros paslaugu teikimas sudaro galimybes aukštesnei gyvenimo gerovei formuotis ir tikslinga dèmesi atkreipti i šių paslaugu teikimo galimybes pagal gyvenamają vietovę, atsižvelgti i tai, kaip vietos gyventojai jaučiasi ir vertina šias paslaugas bei kaip vertina savo būsimą gyvenimą.

Raktiniai žodžiai: socialinè infrastruktūra, socialinès infrastruktūros paslaugos, vietos bendruomenè, kaimo vietovè, gerovè

\section{Introduction}

Social infrastructure (further SI) services, in a broad sense, are understood as various services (education, medical, post, transport, personal security, communication, public catering etc.) usually provided by mostly public sector institutions in Lithuania. However, SI services do not mean the same or do not cover social services, because social services are specified and cover social protection services (including social care, social support and the like). Accordingly, it should be emphasized that the authors abstract from the specific social services analysis, which are straight, refers to social protection system.

SI services play crucial role in shaping the Lithuanian society as well as the economy of different territorial levels. Furthermore, they make major contribution to the wellbeing of local communities, 
enable many people to participate fully in the society, and promote economic development. In view of the above, it is very important to understand the interplay between the services targeted at improving wellbeing of the community members and their impact on shaping social relations of local community and physical environment within the community life. Public provision of various services is acknowledged as fundamental principle and human right to use it in majority of the European countries (White, Ellison, 2007; Martens, 2011; Social..., 2014). Although it is supposed to be the same regardless of the territorial level, current situation shows inadequacy in provision of SI services, which is considered to be the factor of wellbeing. Scientific literature reveals (Suharto et al., 2010; Woodcraft et al., 2012; Clarence, Gabriel, 2014; Atkočiūnienè et al., $2015)$ that developed SI services positively create significant conditions for community wellbeing: support growing population, assist with integration of new and existing communities, enhance economic prosperity, increase capacity to attract investment, forms attractive image of a local area, etc. However, the impact of inadequate social infrastructure becomes evident when services fail to satisfy local area community needs (as different challenges are faced throughout the structure of society), services are no longer provided, the existing demand for services is inconsistent with the supply, local authorities are incapable of responding to opinion of the local population in relation to diversity of the services. This means that local community cannot grow without critical supportive social infrastructure and is accompanied by decrease in judgement in relation to wellbeing.

The research presented in this paper analyses SI services as a factor of rural community wellbeing. Various aspects of SI services have received fairly limited attention in Lithuanian social sciences. The main directions of analysis of SI services observed fall under the fields related to mechanisms of SI reformation (Žalimienè, 1993), evaluation of the overall situation of SI (Atkočiūnienè, 2000), Lithuanian inhabitants' needs (Kuliešis, Vidickienè, 2008; Engle et al., 2014), their role to sustainable communities (Atkočiūnienè et al., 2015; Vaznonienè, 2015). Certain other aspects are not as significant or cover the fields mentioned only partially. In view of the above, the need to discuss the role of SI services for promotion of local community wellbeing is becoming increasingly relevant and requires greater attention from the researchers.

In view of the novelty and relevance of the topic, the research object is social infrastructure services as a factor of local community wellbeing. The aim of the research is to reveal the importance of social infrastructure services in promotion of local community wellbeing. The research question of the article is formulated as follows: how social infrastructure services contribute and could promote wellbeing of the local community. The research aim is achieved by implementing several research objectives: first, the role of SI services for the local community wellbeing is revealed; second, empirical research methodology is presented, and finally, the results of empirical research are discussed. Theoretical and empirical research methods have been employed: analysis and synthesis of scientific literature and documents, abstraction, comparative analysis, questionnaire survey.

\section{Theoretical background}

\subsection{Conceptualisation of the role of social infrastructure in local community wellbeing}

The role of social infrastructure services has increased over the recent decades, but due to the financial and economic crises, demographic challenges, there has been a shift in understanding of how SI services should serve people. The main idea is that support for SI services should enhance social and economic development of different countries (White, Ellison, 2007; Commission..., 2011; Woodcraft et al., 2012; Role..., 2012; Yu Chia-Pin et al., 2016). As the importance of SI services for the states and society has been growing in the recent decade, alignment of the services with the needs of population is becoming increasingly relevant (Suharto et al., 2010; Campbell, 2011; Yonk, Reilly, 2012; Social..., 2014; Antonyuka et al. 2015). Moreover, satisfaction of the needs largely determines the wellbeing of population.

The concept of wellbeing is frequently discussed and debated among scholars of various scientific fields. It should be noted that this article does not pursue an objective to describe the evolution of the concept of wellbeing concept. The attention, however, is focused on how this multidimensional concept is disclosed in the context of SI service provision. The objective of exploring the concepts 
of "society" and more locally, "community", has increasingly intersected with a new set of notions - sustainability, wellbeing and quality of life. The literature on wellbeing (Gasper, 2004; Magee et al., 2012; Measuring..., 2013; Social..., 2014; Engle et al., 2014; Mensah et al., 2016) reveals considerable eclecticism that exists among the proposed indicator systems, with variation introduced by scope (global, national or community-based), domain (life versus domain satisfaction), demographic, geographic and cultural factors, orientation, theoretical conceptions and empirical findings of wellbeing interpretations. The concept of wellbeing reveals the features and properties of people's material and cultural living conditions compared with a standard or a certain level and adequate satisfaction of those conditions (Allister McGregor, 2006; Cattell et al., 2008; Well-being..., 2011; Mensah et al., 2016). In view of the above, local wellbeing is usually related to local communities, place-based approach, targeted areas (with specific vulnerable, social risk groups, etc.). Subjective wellbeing data is obtained by conducting surveys and account for people's own aspirations, perceptions and evaluations of their experiences related to development of personal, living environment. It should be noted that the essence of wellbeing is related to various life aspects or domains which largely involve SI services as well: living in attractive and healthy environment, the desire to live long in health, to be educated, ambition to live safe etc. Researchers (White, Ellison, 2007; Pichardo-Muñiz, 2011; Shannon et al., 2011; Antonyuka et al., 2015; Murgaš, Klobučník, 2016) have concluded that community wellbeing implies a community infrastructure that is accessible and available to all and supports the gathering of residents, healthy ecosystems that provide the region with valuable resources which support the sense of place. Antonyuka et al. (2015) have defined wellbeing/quality of life as an aggregate of objective and subjective conditions for existence and development of personality (reproduction potential, living conditions, level of income, and satisfaction with consumption of social benefits).

In conceptualisation of SI services, they could be described in several ways. Swanson (1992) has emphasized that $\mathrm{SI}$ is formed of the following elements: institutions providing social services/consultations (local administration, institutions providing social services, NGOs), human resources (skills, level of education, social structure of local residents/employees), characteristics of social ties (ability to develop innovations, to take over the information, etc.). Cavaye (2001) has pointed out that SI increases the choice, sustains positive attitudes, improves the function of institutions, creates better conditions, and enhances wellbeing. Zizys et al. (2004) have characterized social infrastructure as the institutions that act as the building blocks of civil society, the places where the community sector functions (community centres, meeting places), where organizations receive support in formation and growth, and where social capital is created. Rothman (2005) has defined infrastructure as a complex system of facilities, programmes, and social networks that aimed at improving people's wellbeing/quality of life and forming the foundation of a strong neighbourhood. Communities and services can work together to decide what needs to be done, and how it is going to be done - so that services are consistent with community needs (Commission..., 2011). In the report "Role of social infrastructure in local and regional economic development" (Role..., 2012, p. 2), SI is viewed as "the interdependent mix of facilities, places, spaces, programs, projects, services and networks that maintain and improve the standard of living and wellbeing/quality of life in a community". Woodcraft et al. (2012) have noted that SI services are important for creating sustainable, successful places that promote wellbeing by exploring what people need from the places they live and work. He has asserted that there is a strong link between the quality of SI in communities and, in particular, the wellbeing of new residents intending to live in rural area. The researcher's central idea is that SI services should shape "walking distance communities", where local community wellbeing is higher when $\mathrm{SI}$ is formed by the nearness (closest SI) facilities. Yonk and Reilly (2012) have mentioned that participatory activities and successful arrangements in SI institutions increase individual's life satisfaction. Clarence and Gabriel (2014) have revealed that SI services are an important element of community social action and interaction, the way how people are engaged. All above mentioned scientists disclose wide range of ways, methods in which individuals, communities, organisations and businesses can seek better wellbeing through their choices, actions and commitments to address the social issues. Moreover following the Rural Development Programme 2014-2020 (2015, p. 102-103), it is seen that one target direction implementing local development strategies in the rural areas emphasize possible support for public infrastructure creation and maintenance, promotion of economic and social cultural activities in the ordered objects. As well as 
communication, transport infrastructure and the accessibility of these services are emphasized as ways for reducing local residents' social exclusion and poverty, enhancing rural vitality. So this coincide the idea that SI services as a part of public infrastructure provide positive social and economic effects on local community wellbeing.

As in this article, authors focus attention on rural social infrastructure defined as a territorial and spatial system of interrelated types of economic and social activity and relations which create conditions for functioning of ecosystems, creation of human, physical and social capitals employed by individuals and community in satisfying their individual and social demands (Atkočiunienè et al., 2015). Vaznonienè (2015) has explained that rural SI is the key part of rural social and economic system, with its level of development predetermining the satisfaction of rural residents' needs, fulfilment of their range of choice and alternatives that affect overall wellbeing.

Literature analysis has established that provision of social infrastructure positively influences economic growth and social development in a variety of ways. In summary, it could be stated that various approaches to $\mathrm{SI}$ emphasize that $\mathrm{SI}$ is not just about SI objects (buildings), but it is rather much more important to discuss its functions and benefit for local community (Table 1).

Tab 1. Social and economic effects of SI on local community wellbeing (made by the authors according to Gilroy, 2006; Shannon et al., 2011; Martens, 2011; Role..., 2012).

\begin{tabular}{|c|c|c|}
\hline & SOCIAL effects on local community wellbeing & $\begin{array}{l}\text { ECONOMIC effects on } \\
\text { local community wellbeing }\end{array}$ \\
\hline 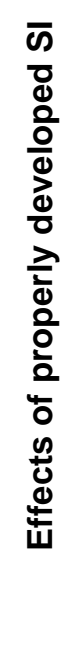 & $\begin{array}{l}\text { - Enhances social interaction, increase social connections } \\
\text { - Strengthens the sense of place and local identity } \\
\text { - Encourages community partnerships } \\
\text { - Enables assessment of social capital in a rural area } \\
\text { - Promotes equality of civic engagement across the rural } \\
\text { community } \\
\text { - Raises community need satisfaction with services and living } \\
\text { conditions } \\
\text { - Strengthens capabilities of different social groups in the local } \\
\text { community } \\
\text { - Contributes to health improvement priorities } \\
\text { - Attracts newcomers to rural area } \\
\text { - Support stable rural community without excluding certain } \\
\text { social groups }\end{array}$ & $\begin{array}{l}\text { - Opportunities for local } \\
\text { ownership, } \\
\text { entrepreneurship, } \\
\text { employment } \\
\text { - Opportunities for public } \\
\text { private partnerships } \\
\text { - Increases capacity to } \\
\text { attract further investment } \\
\text { - Improves standard of living } \\
\text { in the rural area } \\
\text { - Reduces material } \\
\text { deprivation } \\
\text { - Stimulates socially } \\
\text { conscious markets }\end{array}$ \\
\hline
\end{tabular}

The presented actualisation of SI services demonstrates that any community is capable of functioning successfully as long as certain level of development of the services is achieved. Needs of rural community as well as opportunities to satisfy them are one of the most important factors affecting the demand and supply of SI services. Needs of rural community being the social determinants of higher wellbeing could motivate, stimulate or limit SI development. However, as Campbell (2011) has emphasized, for some rural areas, specific public services are more important than their diversity due to their higher impact on improvement of people's wellbeing. It could therefore be asserted that the ultimate aim of the SI services related to local community wellbeing is building attractive, viable, safe and well-connected communities. This approach is close to the concept of sustainable development, where the importance of balanced short-term needs is emphasized along with the ability to meet much more important long-term needs (Allister McGregor et al., 2009; Woodcraft et al., 2012; Clarence, Gabriel, 2014). Martens (2011, p. 27) has noted that it is indisputable that equal and free access to basic services such as health and education and the right to pensions, unemployment benefits, etc., provided by the welfare state, strongly contribute to people's sense of well-being. The above observations suggest that assets provided by SI in rural areas improve human development (in particular, in terms of the "bottomup" approach), wellbeing and living standards. 
It could be concluded that community wellbeing and its relation to SI services is mostly understood from subjective perspective based on individual perceptions of how every member of the community views good life. Accordingly, every community actor seeking positive changes in SI service provision should be active in including service users and providers, professionals, public sector organisations, political leaders and their constituents. The greatest challenge associated with SI services in promotion of rural community wellbeing is to combat the negative outcomes for individuals and communities arising from deep-rooted inequalities and territorial disparities.

\section{Research methodology}

Classical research methods intended to disclose how SI services influence rural community's wellbeing have been employed for substantiation of the empirical research steps. Efforts to measure SI relations with local community wellbeing are the matter of discussion that confronts methodological dilemmas. As Magee et al. (2012), Vaznonienè (2015) has pointed out that these dilemmas arise between objective and subjective evaluation, between "communities" as the sumof-their-parts, between present and future aspects to be measured and between use of "topdown" and "bottom-up" indicators. The research strategy priorities usually depend on the researcher's aims. The rationale behind questionnaire survey chosen as the method for substantiating SI and local community wellbeing relations builds on the idea that this method provides more personalised and user-centred (from the individual's perspective) information; responses reveal the SI services prioritised by people. They employ the results to explore how public SI services could be redesigned according to the local community opinion. In this case, quantitative approach by applying questionnaire method has been chosen with the emphasis on "bottom-up" approach (subjective evaluations) and the authors abstract from objective evaluations in this article (though they are published in other works of mentioned authors). The benefit of subjective evaluation of SI services manifests itself in the political (e.g., local authority), institutional (e.g., promotion of partnership between sectors), residents' need satisfaction (e.g., empowerment, cooperation) perspectives. Martens (2011) has noted growing evidence that personalisation is effective in meeting service users' needs more directly.

Schuessler, Fisher (1985), Boldero (2006) followed theory of human needs and resources and emphasized their particular role when designing a questionnaire as a research toolkit, as it emphasized the link between needs (in this case, needs for SI services in rural areas) and resources that support the possibilities for people to use the human rights. This idea becomes evident in the context of sustainable society and, in particular, where the wellbeing of local residents, communities is concerned. Person's need satisfaction is one of the primary conditions for human wellbeing. Resource accessibility and allocation/distribution between individual groups of people/social groups, different territories influence every person's wellbeing. As noted by Shuessler and Fisher (1985, p. 142), it is highly important to meet multiple needs rather than material needs only (although they provide the possibility of choice) in evaluation of person's wellbeing. Whereas the needs are variable and tend to expand, the need for SI services in rural areas may change respectively. It is also important to consider whether the need satisfaction has positive or negative effect on a person's wellbeing (Boldero, 2006; Haybron, 2011; Measuring..., 2013). Allister McGregor (2006) asserts that needs not only warrant person's life satisfaction in his/her living area, but also enable the person to maintain relationship with others; moreover, emerging needs are the basis of social interaction. Gasper (2004), Allister McGregor (2006, 2009) have emphasized that the concept of wellbeing can be built on the "bottom-up" approach, i.e., by starting with resources by virtue of the possibilities of choice and their alternatives, and activity that helps achieve satisfaction and consistency of values.

Anonymous questionnaire has been developed for analysis of residents' needs and situation of $\mathrm{SI}$ in the rural area. The data gathered have been generalised without highlighting any individual respondents' answers. Question blocks (analysed attributes) formed in the questionnaire are based on the foreign and Lithuanian authors' theoretical insights on SI in rural areas, theory of human needs/resources (Žalimienè, 1993; Atkočiūnienè, 2000). The method of questionnaire survey has enabled the authors of the paper to explore, determine, assess the scope, relevance of the issue, causal links, identify the respondents' opinion on the current situation of SI in the rural 
area and existing shortcomings of the SI objects in rural areas and, in general, demonstrates the attractiveness/issues of the residential area that are topical to local residents, interaction between SI services and wellbeing. Results presented in the article represent only part of the research, as the questionnaire has included a variety of SI-related questions.

Tab 2. Questions' groups and their aims.

\begin{tabular}{|c|c|}
\hline $\begin{array}{l}\text { Questions' groups (number of } \\
\text { questions) }\end{array}$ & Aims of the questions \\
\hline $\begin{array}{l}\text { 1. Respondents' demographic, social, } \\
\text { economic characteristics (15) }\end{array}$ & $\begin{array}{l}\text { To identify demographic, social, economic characteristics of } \\
\text { respondents from the pilot areas. }\end{array}$ \\
\hline 2. General evaluate of SI situation (3) & $\begin{array}{l}\text { To determine the respondents' general views towards } \\
\text { the situation of SI objects in their residential area. }\end{array}$ \\
\hline $\begin{array}{l}\text { 3. Situation of education, training and } \\
\text { consultancy (10) }\end{array}$ & $\begin{array}{l}\text { To determine the respondents' views towards the services } \\
\text { provided by education, training, consultancy and culture } \\
\text { objects and their quality. }\end{array}$ \\
\hline $\begin{array}{l}\text { 4. Situation of health and social } \\
\text { security sector (2) }\end{array}$ & $\begin{array}{l}\text { To analyse the quality of services provided by health and } \\
\text { social security objects. }\end{array}$ \\
\hline $\begin{array}{l}\text { 5. Situation of transport, } \\
\text { communications and } \\
\text { telecommunication sector }(6)\end{array}$ & $\begin{array}{l}\text { To analyse the respondents' views towards operation of } \\
\text { transport and communications sectors and the quality of } \\
\text { services provided by them. }\end{array}$ \\
\hline 6. Personal and property protection (4) & $\begin{array}{l}\text { To determine how personal and property protection is } \\
\text { secured in the pilot areas. }\end{array}$ \\
\hline 7. Utilities and municipal services (3) & $\begin{array}{l}\text { To analyse the respondents' opinion on the situation of } \\
\text { utilities, municipal and trade objects, provision of and need } \\
\text { for the related services. }\end{array}$ \\
\hline $\begin{array}{l}\text { 8. Assessment of issues of the living } \\
\text { area (2) }\end{array}$ & To identify the issues existing in pilot areas. \\
\hline 9. Disadvantages of the living area (5) & $\begin{array}{l}\text { To determine the shortage of SI objects/services and what } \\
\text { should be established in the pilot areas. }\end{array}$ \\
\hline
\end{tabular}

Though questions are largely based on evaluation of SI services, the assumptions (as noted in other literature as well) (White, Ellison, 2007; Gopalakrishna, Leelavathi, 2011; Haybron, 2011; Clarence, Gabriel, 2014; Antonyuka et al., 2015 etc.) that they have effect on local community's wellbeing have been taken into account. Moreover, needs for these services are a significant factor that helps explore the demand for SI services in response to human diversity. Main question groups are detailed below (Table 2). Questions mostly related to SI and wellbeing are detailed in the results part.

The practical value of this toolkit is based on several aspects:

- it allows to identify the residents' potential initiatives on improvement of the situation (e.g., by improvement of accessibility via mutual agreements);

- different departments of the municipalities (education and culture; municipal, etc.) may perform prompt (self-) evaluation of the overall situation of the SI in their respective districts according to the residents' opinion; identify the residents' needs for improvement, development of a certain sector, etc.;

- it is important that the situation of SI objects, quality of the activities and services provided, and residents' needs are identified under a cross-cutting approach: e.g., by social groups, importance of residents' economic activity; similarities and divide between municipal centre (city, town) and rural areas; the idea of partnership between public, private sectors and NGOs for addressing improvement and development of SI.

Research sample. Results of this research are aimed at measuring the subjective attitudes of the pilot areas communities towards SI services. It focuses on both current situation of SI services and future wellbeing of the community. The research results are presented on the basis of 5 municipality cases (Alytus distr., Rietavas distr., Pasvalys municipality, Kaišiadorys distr., 
Kèdainiai distr.), i.e., more rural townships have been chosen for the research in order to identify their views towards the need for SI services and the services, organisations that the rural residents would need the most for improvement of their lives in the rural areas.

This research has been performed under probability (random) selection methodology, namely, cluster analysis (Atkočiūnienè et al., 2014). The most common type of cluster sampling is sampling by geographical regions. In this case, the pilot districts have complied with specified criteria of applied method and demonstrated the following distinctions: there are particular differences between rural residents, they are located in different regions, and districts consist of townships, some of them of small towns and villages. Statistical table by V.A. Jadov has been used for representative sampling with $5 \%$ error; other possibilities for justification of the sample have also been accounted for, e.g., modern online calculators (Sample Size Calculator: http://www.surveysystem.com/sscalc.htm; Sample Size Calculator:

http://www.calculator.net/sample-size-calculator.html). The calculations have indicated that at least 400 residents of the pilot areas should be included in the survey for research representativeness. Sample of the present research is $N=1023$, where respondents number was calculated accordingly to pilot areas population size: 39 percent represented Alytus district, 33 percent - Kaišiadorys district, 13 percent - Pasvalys district, 9 percent - Rietavas municipality, 6 percent - Kèdainiai district. There were 73 percent women and 27 percent men, from which 58 percent represented rural areas, 30 percent - towns, 7 percent - urban area and 5 percent - steadings. So respondents living in rural areas and steadings made 63 percent from all sample. Data and calculations have been processed using IBM SPSS Statistics Version 20 and Ms Excel software applications.

\section{Research results}

Communities are diverse, and different viewpoints are central to their wellbeing profile. People belong to different communities and they reflect a diversity of interests and needs for SI services. They can provide necessary information and contribute to the development of local policy and practice. The examples outlined in the theoretical part above demonstrate that collaboration between individuals, communities and service providers can turn into important multidimensional partnerships generating wider benefits and building individual and community capacity. Attention has been turned to certain questions, which also consider rural community wellbeing, in order to move deeper into this empirical research. First, respondents expressed their evaluations based on the overall situation of SI (Table 3). The table presents evaluations of the SI sectors based on several variables: general evaluation of the SI situation, gender, social economic group, residential and pilot areas.

As provided in the table, respondents' evaluations based on the overall situation of SI have provided the following results:

- although the evaluation results of the overall SI situation is not very high and is closer to the average; the SI sector of communications and telecommunications has been referred to as the best functioning SI sector, while the sector of personal and property protection has received the worst evaluations - this sector has been referred to as potentially risky to human happiness and possibility to be safe under the place-based approach in the majority of studies (Pichardo-Muñiz, 2011; Magee et al., 2012);

- according to the gender variable, differences between evaluations provided by women and men for individual SI sectors are different; however, evaluations regarding the worst and best functioning sector are the same; transport services have been found to receive rather low evaluation scores, taking into consideration that evaluations related to these services also determine accessibility and availability of other sectors;

- in terms of evaluations by social economic group, evaluations of SI sectors have been observed to be lower among the respondents who have indicated worse situation of their living, for example, the respondents who live in destitute/poverty have referred to 4 sectors as being worse than satisfactory; 
- if viewed by the living areas, evaluations of SI sectors have been observed to be lower in steadings and rural areas than in urban-type areas; the research results have supported the observations by other researchers (Suharto et al., 2010; Planning..., 2012;), namely, than SI planning, monitoring in rural areas requires particular attention due to lower evaluations of wellbeing;

- in terms of SI evaluation by pilot areas, Rietavas distr. has been found to generate lower evaluations of SI compared to other districts; Kèdainiai distr. has provided higher than satisfactory evaluations of all sectors; all districts, however, have demonstrated that personal and property protection calls for greater attention.

Tab 3. Respondents' evaluations based on the overall situation of SI*.

\begin{tabular}{|c|c|c|c|c|c|c|c|c|}
\hline SI sectors & 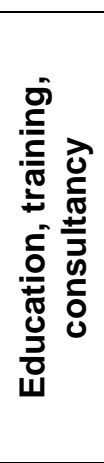 & 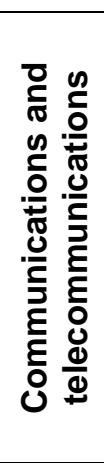 & 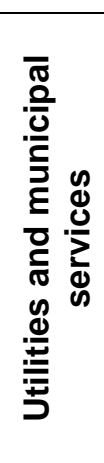 & $\begin{array}{l}\text { t․ } \\
\frac{0}{0} \\
\frac{0}{n} \\
\frac{c}{\sigma} \\
\text { ㄴ }\end{array}$ & 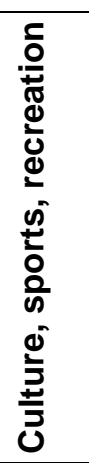 & 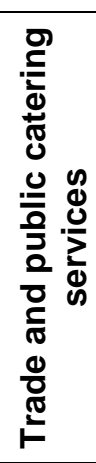 & 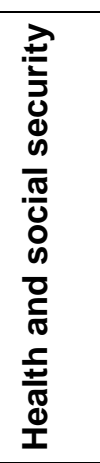 & 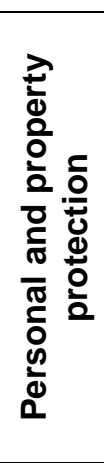 \\
\hline Average evaluation of SI sectors & 3.39 & 3.82 & 3.38 & 3.05 & 3.09 & 3.07 & 3.14 & 2.95 \\
\hline \multicolumn{9}{|c|}{ GENDER } \\
\hline Women & 3.44 & 3.83 & 3.37 & 3.04 & 3.07 & 3.05 & 3.12 & 2.92 \\
\hline Men & 3.27 & 3.78 & 3.40 & 3.07 & 3.13 & 3.10 & 3.20 & 3.01 \\
\hline \multicolumn{9}{|c|}{ SOCIAL ECONOMIC GROUP } \\
\hline I am just subsisting & 3.42 & 3.69 & 3.29 & 2.83 & 3.28 & 3.20 & 3.09 & 2.79 \\
\hline I live in destitute/poverty & 3.38 & 3.88 & 3.05 & 2.69 & 2.93 & 2.93 & 2.95 & 2.56 \\
\hline My life is normal/well-off & 3.36 & 3.79 & 3.36 & 2.98 & 3.06 & 3.08 & 3.15 & 2.91 \\
\hline My life is good & 3.48 & 3.83 & 3.46 & 3.28 & 3.13 & 3.04 & 3.19 & 3.17 \\
\hline My life is very good & 3.38 & 4.41 & 4.03 & 3.79 & 3.41 & 3.22 & 3.09 & 3.06 \\
\hline \multicolumn{9}{|c|}{ LIVING AREAS } \\
\hline Steading** & 3.08 & 3.50 & 3.26 & 2.67 & 2.92 & 2.90 & 2.98 & 2.88 \\
\hline Rural areas & 3.22 & 3.75 & 3.35 & 3.07 & 2.97 & 2.96 & 3.03 & 2.88 \\
\hline Towns & 3.66 & 3.96 & 3.44 & 3.00 & 3.22 & 3.22 & 3.32 & 2.97 \\
\hline Urban areas & 3.94 & 3.96 & 3.49 & 3.35 & 3.56 & 3.33 & 3.33 & 3.32 \\
\hline \multicolumn{9}{|c|}{ PILOT AREAS } \\
\hline Alytus distr. & 3.42 & 3.84 & 3.40 & 3.13 & 3.30 & 3.08 & 3.20 & 2.98 \\
\hline Kèdainiai distr. & 3.37 & 3.98 & 3.19 & 3.26 & 3.02 & 3.20 & 3.04 & 2.42 \\
\hline Kaišiadorys distr. & 3.38 & 3.79 & 3.33 & 2.89 & 2.90 & 3.03 & 3.09 & 2.89 \\
\hline Pasvalys munic. & 3.58 & 3.80 & 3.47 & 2.96 & 3.03 & 3.18 & 3.36 & 3.24 \\
\hline Rietavas distr. & 3.12 & 3.81 & 3.40 & 3.19 & 2.95 & 2.83 & 2.90 & 2.83 \\
\hline
\end{tabular}

* SI situation has been evaluated on the 5-point scale, where: 1 - very bad situation, 5 - very good situation.

** According to the state law "Law on the territorial administrative units and their boundaries" (2010) (in Lithuanian "Lietuvos Respublikos teritorijos administracinių vienetu ir jų ribu istatymas") steading shall be historically formed residential areas typically made up of or originating from a single homestead with no more than 20 objects each at a different address. 
Another question aimed at identifying the needs for SI services and improvement of wellbeing is "What does your family lack the most?" (Fig. 1).

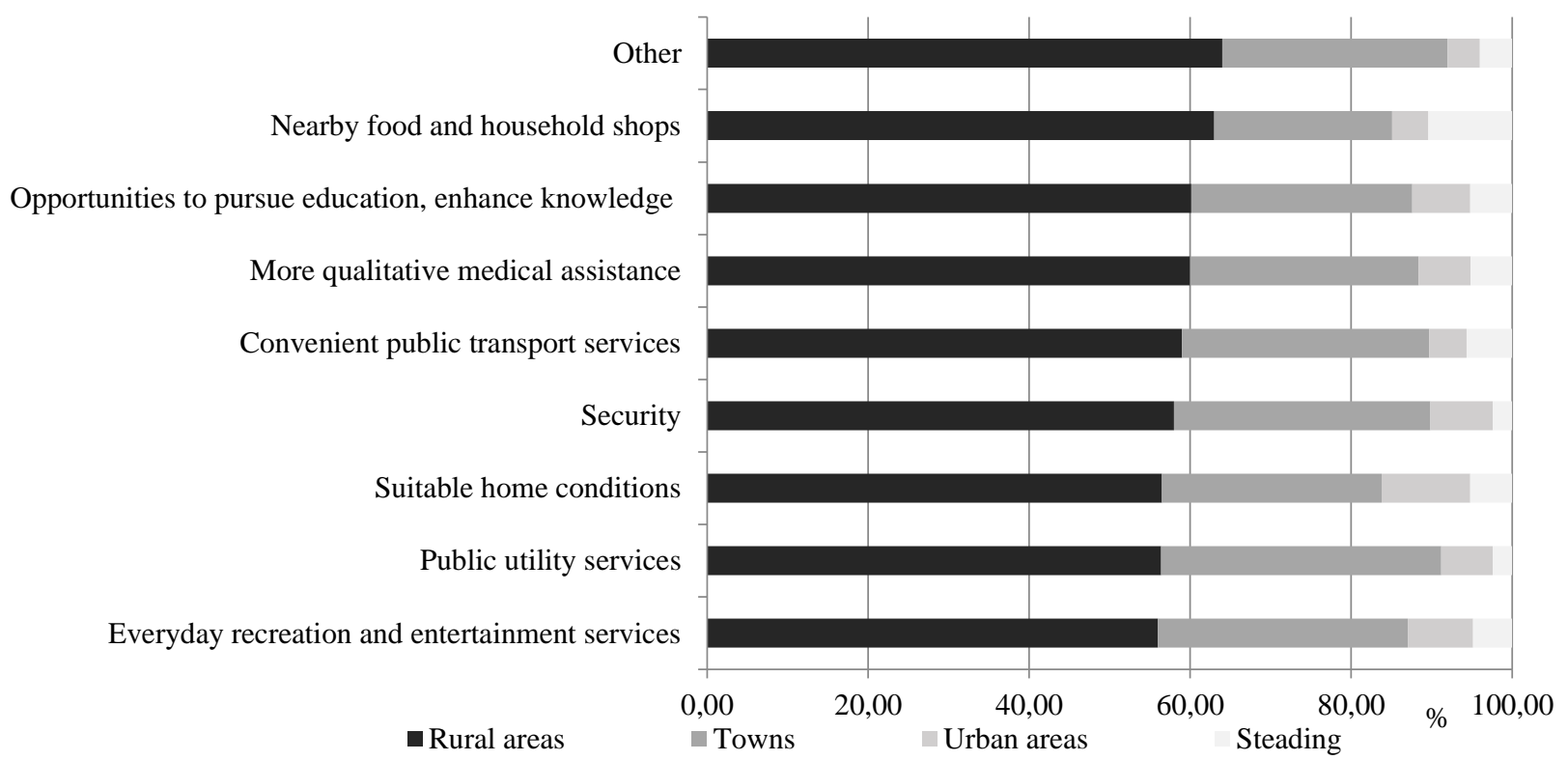

Fig 1. SI services reported by the respondents as lacking for their families, percentage.

In view of the purpose of this research, rural community needs for SI services must be identified, and the most important SI service groups in rural areas (referred to by over $50 \%$ of residents) have been found to be other services (however, they have not been specified by the residents), nearby food and household shops, opportunities to pursue education, enhance knowledge, and need for medical assistance. It should be noted that these services are most often referred to as basic services, although they are not always easily available or accessible in rural areas due to public transport. Shortage of the services mentioned also highlight their perception of wellbeing and its inconsistency with the actual situation, as the expectations of better life are met insufficiently. In terms of the age groups in pilot districts, the following trends of shortage reportedly experienced by the respondents' families have emerged:

- age group < 29 (youth) has reported the greatest shortage of conditions for daily recreation and entertainment $(51 \%)$, convenient public transport services $(36 \%)$, and quality medical assistance (35\%);

- age group 30-59 has reported the shortage of conditions for daily recreation and entertainment, and quality medical assistance (40\% each), convenient public transport services (38\%), and public utility services $(36 \%)$;

- age group $60<$ (the oldest age group) has reported the greatest shortage of convenient public transport services (44\% of the respondents), public utility services, and quality medical assistance ( $41 \%$ each), while shortage of security has been reported by $32 \%$ of the respondents in this age group.

Open-ended question ("What else would you recommend to improve in operation of social infrastructure in your residential area?") has been aimed at identifying the opinion of residents in the pilot areas about the SI changes that would contribute to improvement of the residential environment and improvement of their wellbeing (Table 4). As the SI evaluation under this research is based on SI sectors, the aim has been to identify the SI services reported by the residents as being in the greatest demand in their respective residential areas. 
Tab 4. Respondents' (percent) opinion about improvement and need for changes of SI sectors.

\begin{tabular}{|l|c|c|c|c|c|}
\hline \multicolumn{1}{|c|}{ SI sectors } & $\begin{array}{c}\text { Rietavas } \\
\text { distr. }\end{array}$ & $\begin{array}{c}\text { Alytus } \\
\text { distr. }\end{array}$ & $\begin{array}{c}\text { Kèdainiai } \\
\text { distr. }\end{array}$ & $\begin{array}{c}\text { Pasvalys } \\
\text { munic. }\end{array}$ & $\begin{array}{c}\text { Kaišiadorys } \\
\text { distr. }\end{array}$ \\
\hline Culture, sports, recreation & 5 & 41 & 0 & 35 & 19 \\
\hline Transport & 24 & 16 & 17 & 12 & 12 \\
\hline Utilities and municipal services & 10 & 9 & 58 & 15 & 32 \\
\hline $\begin{array}{l}\text { Trade and public catering } \\
\text { services }\end{array}$ & 0 & 7 & 0 & 0 & 0 \\
\hline Health and social security & 17 & 5 & 8 & 4 & 8 \\
\hline Education, training, consultancy & 2 & 3 & 0 & 0 & 8 \\
\hline Personal and property protection & 2 & 3 & 8 & 4 & 1 \\
\hline $\begin{array}{l}\text { Communications and } \\
\text { telecommunications }\end{array}$ & 15 & 1 & 8 & 0 & 4 \\
\hline All sectors should be improved & 0 & 1 & 0 & 0 & 0 \\
\hline Uncertain/no opinion & 7 & 15 & 0 & 8 & 2 \\
\hline Changes are not desired & 7 & 0 & 0 & 0 & 0 \\
\hline Another & 10 & 1 & 0 & 23 & 13 \\
\hline Total & 100 & 100 & 100 & 100 & 100 \\
\hline There is a need for RSI changes & 82 & 81 & 100 & 90 & 95 \\
\hline No need for RSI changes & 18 & 19 & - & 10 & 5 \\
\hline
\end{tabular}

The respondents' opinion has revealed that the situation of SI services in future will be related to specific needs of various target groups as well as to various life domains (social, economic, political) of their wellbeing. In terms of consistency of the insights under this research with the findings generated by other research works (White, Ellison, 2007; Gopalakrishna, Leelavathi, 2011; Antonyuka et al., 2015), the latter have also been found to emphasize that wellbeing of rural communities (rural residents) is higher, where the residential area is located in a more attractive natural environment, closer to larger cities. Based on the table above and other subjective evaluations of respondents', the needs expressed by respondents suggest the following aspects that are important for initiation of SI changes:

\section{Orientated directly to SI changes:}

- transport: <...we need convenient public transport to commute to the nearest towns, as there is almost no public transport at present; roads must be paved; public transport operations must be improved...>;

- health and social security: <...better health care to disadvantaged families and seniors; stop paying allowances to alcohol abusers. They should start working, if not - go to jail; take care of people, provide help, not hurt them; take greater care of lonely people...>;

- utilities and municipal services: <...maintenance of public order; there are so many ruins in critical condition in the village, common order is required...>;

- education, training, consultancy: <... consultations and training not only for women, but also for men must be improved at all community centres; more attention should be given to activities of youth and teenagers; centres necessary for various activities must be equipped in vacant buildings; various workshops and trainings should be organised...>;

- personal and property protection: <...security is the most important; police volunteer patrol is necessary on the streets in the village, police is required...>.

Directed at other factors that determine wellbeing:

- political domain: <...to replace authority, to elect new members; fewer bureaucrats; new head of community must be elected in the village as soon as possible...>; 
- economic domain: <... to promote business and industry; it is difficult to start doing business; residents' employment rates should be improved by creating new jobs; possibilities for mothers raising children to work according to their specialization part-time...>;

- social domain: <...to promote gender equality in the village without discriminating men or women; the village does not have a working community, but rather has the subsisting community; community awareness should be raised in terms of assistance to others...>;

Positive attitude towards the future of SI operation: <...I am now satisfied with everything; what people need is the desire, and everything will improve; there is no one to make it better but yourself...>;

Negative attitude towards the future of SI operation: <...I do not know, there is no particular demand; everything needs to be improved; there are and might be recommendations, but everything stays within research only... we have already experienced this, it is all in vain; we do not have much to improve...>.

The research has revealed that the evaluations and choices provided by the respondents demonstrate the need of a very wide range of services. It has been recognized that communities themselves should also decide the level of empowerment that they can undertake and desire, and the methods of achieving it. There is no doubt that district municipalities and other local actors should be sensitive to SI planning and changes which have effect on rural areas and manifest themselves in rural community needs.

\section{Conclusions}

Research results revealed that social infrastructure's importance to wellbeing is significant and still not deeply explored in Lithuanian social sciences discourse. It serves shaping both the living territory environment as well as society's wellbeing. As social economic system it forms the living environment features, promotes or reduces the attractiveness of a living space; social infrastructure services enhance or decrease local community wellbeing depending on its development level, supply and accessibility of services.

As the results suggest, the attention to planning or developing social infrastructure services for rural community's wellbeing should be focused on several aspects like emphasizing the impact on various individuals/rural community priority needs and life domains (social, economic, political), social economic status of rural community, features and social economic changes of a rural area.

Recognizing that effective SI services should be designed with and for people, and communities' important step is to harmonize the "top down" and "bottom up" approaches whether to provide the most proper and marketable services for local community. In this case, various local actors' contribution to forming services is important.

The recommendations based on the presented research disclose that these researches are the niche finding closer relations between social infrastructure and community (rural or urban) wellbeing, facing the challenges related to socio-demographic changes of rural community and overall society.

International application and comparison of the used methodology could also be an important factor in developing and broadening the knowledge on how social infrastructure services affects local community wellbeing in different European countries. The used instrument mostly can be easily adopted to local level territories (elderships, municipalities) and regional level.

Academic references

[1] Antonyuka, V. S., Danilova, I. V., Mitelman, S. A. \& Bulikeyeva, A. Zh. (2015). Regional Social Infrastructure Management in the System of Tools Used for Improving the Quality of Life for Regional Population. R-Economy 1(3), 395-407. DOI: 10.15826/recon.2015.3.003. 
[2] Atkočiūnienè, V. (2000). Lietuvos kaimo socialiné infrastruktūra; ekonominis vertinimas ir plètra: daktaro disertacija [PhD Thesis]. Akademija: Lietuvos žemès ūkio universitetas.

[3] Atkočiūnienè, V., Vaznonienè, G. \& Pakeltienè, R. (2015). Aim of the Development of Rural Social Infrastructure: a Sustainable Community. Transformations in Business \& Economics 14(2A), 509-528.

[4] Cattell, V., Dines, N., Gesler, W. \& Curtis, S. (2008). Mingling, observing, and lingering: Everyday public spaces and their implications for well-being and social relations. Health \& Place 14(3), 544-561. DOI: 10.1016/j.healthplace.2007.10.007.

[5] Cavaye, J. M. (2001). Rural Community Development: New Challenges and Enduring Dilemmas. The Journal of Regional Policy Analysis, 31(2), 109-124.

[6] Clarence, E. \& Gabriel, M. (2014). People Helping People: the future of public services. London: Nesta.

[7] Engle, M. \& Altschuld, J. W. (2014). Needs assessment: The perspective from the public sector. In Altschuld, J. W. \& Watkins, R., eds., Needs assessment: Trends and a view toward the future. New Directions for Evaluation (pp. 33-45). Hoboken, NJ: Wiley.

[8] Haybron, D. M. (2011). Central Park: Nature, context, and human wellbeing. International Journal of Wellbeing, 1(2), 235-254. DOI: 10.5502/ijw.v1i2.6.

[9] Gopalakrishna, B. V. \& Leelavathi, D. S. (2011). Infrastructure and Human development in India: An Interstate comparison. Journal of Global Economy, 7(4), 225-244.

[10] Kuliešis, G. \& Vidickienè, D. (2008). Lietuvos kaimo gyventojų nuomonès tyrimai dèl kaimo infrastruktūros gerinimo. Akademija, 12(1), 92-100.

[11] Magee, L., Scerri, A. \& James, P. (2012). Measuring Social Sustainability: A CommunityCentred Approach. Applied Research in Quality of Life, 7(3), 239-261. DOI: 10.1007/s11482012-9166-X.

[12] Martens, H. (2011). The role of public services in enhancing growth and well-being. In: Andor, L. et al., eds., Growth, well-being and social policy in Europe: trade-off or synergy? (pp. 2733). Brussel: European Policy Center.

[13] McGregor, J. A. (2006). Researching Wellbeing: from Concepts to Methodology [WeD Working Paper 20]. University of Bath.

[14] McGregor, J. A., Camfield, L. \& Woodcock, A. (2009). Needs, Wants and Goals: Wellbeing, Quality of Life and Public Policy. Applied Research Quality Life, 4(2), 135-154. DOI: 10.1007/s11482-009-9069-7.

[15] Mensah, C. A., Andres, L., Perera, U. \& Roji, A. (2016). Enhancing quality of life through the lens of green spaces: A systematic review approach. International Journal of Wellbeing, 6(1), 142-163. DOI: 10.5502/ijw.v6i1.6.

[16] Pichardo-Muñiz, A. (2011). The Role of Diseconomies of Transportation and Public Safety Problems in the Measurement of Urban Quality of Life. Applied Research Quality Life, 6(4), 363-386. DOI: 10.1007/s11482-010-9134-2.

[17] Rothman, L. (2005). The Role of Community Infrastructure in Building Strong Neighbourhoods [Final Report]. Toronto: Family Service Association.

[18] Schuessler, K. F. \& Fisher, G. A. (1985). Quality of Life Research and Sociology. Annual Review of Sociology, 11, 129-149. DOI: 10.1146/annurev.so.11.080185.001021.

[19] Shannon, H., Rogers, S. H., John, M., Halstead, J. M., Gardner, K. H. \& Carlson, C. H. (2011). Examining Walkability and Social Capital as Indicators of Quality of Life at the Municipal and Neighborhood Scales. Applied Research Quality Life. 6(2), 201-213. DOI: $10.1007 / \mathrm{s} 11482-010-9132-4$.

[20] Suharto, T., Tan, Y. \& Severine, M. (2011). Social infrastructure planning and sustainable community: example from south east Queensland, Australia. In: Jahan, N., ed., Proceedings 
of the Business and Social Science Research Conference 2011 (pp. 1-12). Berwick: World Business Institute Australia.

[21] Swanson, L. (1992). Rural social infrastructure. In: Reid, J. N., ed., Foundations of Rural Development Policy, Boulder, CO: Westview Press.

[22] Vaznonienè, G. (2015). The role of rural community enhancing rural social infrastructure changes. In: Treija, S. \& Skujeniece, S., eds., Annual 21 $1^{\text {st }}$ International Scientific Conference: "Research for Rural Development" Volume 2, Jelgava, Latvia, 13-15 May 2015 (pp. 176182). Jelgava: Latvian University of Agriculture.

[23] White, S. C. \& Ellison, M. A. (2007). Wellbeing, livelihoods and resources in social practice. In Gough, A. \& McGregor, J. A, eds., Wellbeing in Developing Countries: New Approaches and Research Strategies. Cambridge: Cambridge University Press, pp. 157-175.

[24] Woodcraft, S., Bacon, N., Caistor-Arendar, L. \& Hackett, T. (2012). Design for social sustainability. A framework for creating thriving new communities. London: Young Foundation.

[25] Yonk, R. M. \& Reilly, S. (2012). Citizen Involvement \& Quality of Life: Exit, Voice and Loyalty in a Time of Direct Democracy. Applied Research Quality Life, 7(1), 1-16. DOI: 10.1007/s11482-011-9142-x.

[26] Yu Chia-Pin, Cole, S. T. \& Chancellor, Ch. (2016). Assessing Community Quality of Life in the Context of Tourism Development. Applied Research Quality Life, 11(1), 147-162. DOI: $10.1007 / \mathrm{s} 11482-014-9359-6$.

[27] Žalimienè, L. (1993). Lietuvos kaimo socialinès infrastruktūros pertvarkymo mechanizmas [PhD Thesis]. Vilinius: Institute of Philosophy, Sociology and Law of Lithuanian Academy of Sciences.

\section{Other sources}

[28] Boldero, N. (2006). Strong Communities. Social Infrastructure Plan for Voluntary and Community Action in the Milton Keynes \& South Midlands Growth Area. Voluntary and Community Action South Bedfordshire. Available from: https://www.voluntaryworks.org/sites/voluntaryworks.org/files/files/MKSMSIReportPlan.pdf.

[29] Campbell, A. (2011). Commission on the Future Delivery of Public Services. Produced by APS Group Scotland DPPAS11647 (06/11), 102. Available from: http://www.parliament.scot/ResearchBriefingsAndFactsheets/S4/SB_11-52.pdf.

[30] Gasper, D. (2007). Human Well-being: Concepts and Conceptualizations. In McGillivray, M., ed., Human Well-Being. Studies in Development Economics and Policy (pp. 23-64). London: Palgrave Macmillan. DOI: 10.1057/9780230625600_2.

[31] Law on the territorial administrative units and their boundaries. 2010. As last amended on 30 March 2010 - No XI-709. Vilnius: Republic of Lithuania.

[32] Measuring Well-being for Development. (2013). 2013 OECD Global Forum on Development. Discussion Paper for Session 3.1. Available from internet: www.oecd.org/site/oecdgfd/.

[33] Planning for social infrastructure and community services for urban growth areas. (2012). Implementation Guide. Available from internet: https://www.lga.sa.gov.au/webdata/resources/files/2010_10_Project_Output_Implementati on_Guide_(February_20012)_Development_of_Social_Infrastructure_in_Growth_Corridor s.pdf.

[34] Role of social infrastructure in local and regional economic development. (2012). RDSA Regional Infrastructure Summit. Department of Planning Western Australia. Available from internet: $\quad$ http://www.sgsep.com.au/assets/insights/Linda-Perrine-Social-Infrastructurepresentation-0.pdf. 
[35] Rural Development Programme (2014-2020). 2015. The Ministry of Agriculture of the Republic of Lithuania. Available from:

https://ec.europa.eu/agriculture/sites/agriculture/files/rural-development-20142020/country-files/lt/fulltext_It.pdf.

[36] Social cohesion and well-being in the EU. 2014. Bertelsmann Stiftung, Eurofound. Available from: http://eurofound.europa.eu/sites/default/files/ef_publication/field_ef_document/ef1472 en.pdf.

[37] Well-being in 2030. (2011). Aggregate report. Eurobarometer Qualitative studies. Available from: http://ec.europa.eu/public_opinion/archives/quali/wellbeing_aggregate_en.pdf.

[38] Well-being in 2030. (2011). Aggregate report. Eurobarometer Qualitative studies. Available from internet: http://ec.europa.eu/public_opinion/archives/quali/wellbeing_aggregate_en.pdf

[39] Zizys, T., Kosny, M. \& Bonnell, J. (2004). A Review of Social Planning Activities in the City of Toronto. Toronto: Social Development and Administration Division of Community Neighbourhood Services Department of the City of Toronto. 